\title{
Widespread dieback in a foundation species on a sub-Antarctic World Heritage Island: Fine scale patterns and likely drivers
}

\section{Authors:}

Dickson, Catherine R. a , Baker, David J. a, Bergstrom, Dana M. ${ }^{\text {b }}$ Brookes, Rowan H. ${ }^{\text {c }}$, Whinam, Jennie d, McGeoch, Melodie A. ${ }^{\text {a }}$

\section{Author affiliations:}

${ }^{a}$ School of Biological Sciences, Monash University, Clayton 3800, VIC, Australia. cath.dickson@monash.edu, david.baker1@monash.edu, melodie.mcgeoch@monash.edu.

${ }^{\mathrm{b}}$ Australian Antarctic Division, Department of Agriculture, Water and the Environment, Kingston 7050, TAS, Australia.dana.bergstrom@awe.gov.au

${ }^{c}$ Melbourne School for Professional and Continuing Education, The University of Melbourne, Melbourne 3010, Vic, Australia. rowan.brookes@unimelb.edu.au

${ }^{\mathrm{d}}$ School of Technology, Environments and Design, University of Tasmania, Hobart 7001, TAS, Australia. j.whinam@utas.edu.au

\section{Corresponding author:}

Catherine R. Dickson, School of Biological Sciences, Faculty of Science, 25 Rainforest Walk, Monash University, Clayton 3800, VIC, Australia, cath.dickson@monash.edu, +61 399050023

\section{Acknowledgements and funding statement:}

We thank Dr Patricia Selkirk and Dr Grant Duffy for constructive discussions about the manuscript, and John Burgess and Rowena Hannaford for assistance with field work. We thank the handling editor and reviewers for their comments on the manuscript. This study was funded by an Australian Government, Australian Antarctic Science Program Grant (\#4312) and an Australian Government Research Training Program (RTP) Scholarship, the Holsworth Wildlife Research Endowment and The Ecological Society of Australia, and the Denis and Maisie Carr Award.

\section{Data availability statement:}

The data is archived at the Australian Antarctic Data Centre, http://dx.doi.org/doi:10.26179/5e71aba2c846a. The metadata is currently available, however, until manuscript is published the dataset is embargoed. Following publication the data will be released in full.

This is the author manuscript accepted for publication and has undergone full peer review but has not been through the copyediting, typesetting, pagination and proofreading process, which may lead to differences between this version and the Version of Record. Please cite this article as doi: 10.1111/AEC.12958

This article is protected by copyright. All rights reserved 
Dickson C. R., McGeoch M. A., Bergstrom D. M., Whinam J. \& Baker D. J. (2020) Fine-scale Azorella macquariensis condition and site microclimate extremes data from Macquarie Island, v1. (ed Australian Antarctic Data Centre - http://dx.doi.org/doi:10.26179/5e71aba2c846a).

\section{Conflict of interest disclosure:}

The authors declare there are no conflicts of interest associated with this publication.

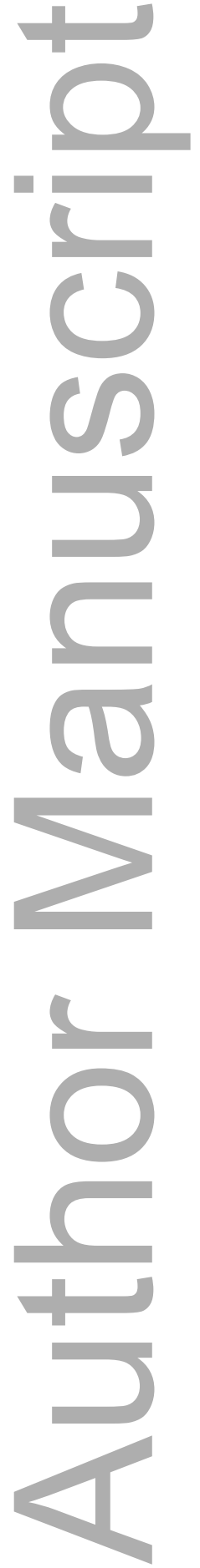

This article is protected by copyright. All rights reserved 
Article type : Research Article

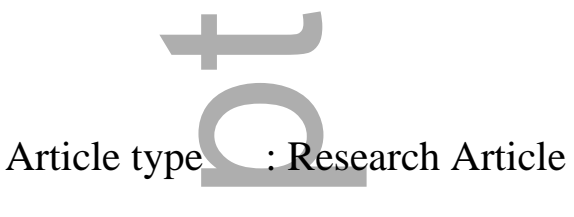

8 Widespread dieback in a foundation species on a sub-Antarctic World Heritage Island:

$9 \quad$ Fine scale patterns and likely drivers

10 Abstract

11 Under anthropogenic climate change, emerging diseases and pathogens are increasingly

12 prevalent in high latitude and altitude regions that were previously protected by cold winter

13 temperatures. Ongoing island-wide dieback of a foundation species, the cushion plant

14 Azorella macquariensis, on World Heritage listed Macquarie Island provides the first sub-

15 Antarctic example. To better understand the island-wide progression of cushion dieback and

16 its drivers, we established and quantified plant condition classes and measured microclimate

17 across 62 sites. We then tested whether the drivers of cushion dieback were associated with (i)

18 water-stress: represented by vapour pressure deficit, wind exposure and gravel content, (ii) pathogen virulence: using freezing days and extreme humidity as empirically supported surrogates, or (iii) both. There was a strong north-south progression in cushion condition, with dieback most active in the centre of the island and advanced in the north. Dieback was most extensive at sites with fewer freezing days and high humidity. Natural southern refugia were explained by the significantly colder temperatures, associated with a north-south temperature gradient. It is expected that under current climate change trajectories, where Macquarie is likely to continue to become warmer and wetter, cushion dieback will remain pervasive, expanding most slowly in the south and potentially outpacing recovery. We emphasise the need for increased awareness to prevent the establishment of pathogens into and across the landscapes of newly susceptible high latitude and altitude regions. Areas of 
high conservation significance need to be prioritised for management, to prevent further landscape-scale change under current climate trajectories.

\section{$31 \quad$ Keywords}

Azorella, sub-Antarctic, climate change, pathogen, microclimate

Introduction

Natural World Heritage Sites (NWHS), inscribed for beauty and biological diversity, are increasingly threatened by the loss of dominant vegetation from intensifying human pressures (Allan et al. 2017). Instances of loss are occurring globally, including at NWHS sites with high levels of protection, due to pressures from pests and diseases emerging with climate change (Allan et al. 2017). Impacts from emerging diseases and pathogens are anticipated to continue to increase (Harvell et al. 2002; Hoberg and Brooks 2015). Under rapidly changing climate conditions, plants are maladapted to the threat of novel pathogens and can have little or no evolved resistance to them (Stenlid and Oliva 2016). In both agricultural and natural systems landscape-scale plant mortalities have often been associated with warmer and wetter conditions, where less extreme minimum temperatures and leaf surface wetness are increasing the prevalence of plant diseases and pests (Anderson et al. 2004; Garrett et al. 2016; Harvell et a1. 2002). For example Xylella fastidiosa (Proteobacteria), a plant pathogen from the Americas with a broad host range, is predicted to expand further through Europe, and potentially globally, under future climate conditions (Sicard et al. 2018). Similarly, and despite being well protected, North American NWHS are considered to have the highest threat of dominant vegetation loss from an increase of Mountain pine beetle (Dendroctonus ponderosae) populations during years with higher minimum temperatures and reduced precipitation (Preisler et al. 2012). The negative consequences of these increasing pathogen and pest footprints are likely to be severe for biodiversity (Harvell et al. 2002) and ecosystem services (Boyd et al. 2013).

Higher elevation and latitude sites are particularly susceptible to novel pathogens as historically cold climates become warmer and experience fewer extreme cold events (Pauchard et al. 2016). The increasingly mild winter conditions and lack of extreme cold events allows for higher pathogen survival in several plant species, suggesting disease severity is likely to increase in the future (see Harvell et al. 2002). In these regions, coldadapted plant species may be increasingly susceptible to disease under higher temperatures This article is protected by copyright. All rights reserved 
60

and changing disease communities (Cohen et al. 2019). For example, in response to climate change crop pathogens have moved on average $2.7 \pm 0.8 \mathrm{~km} \mathrm{yr}^{-1}$ poleward since 1960 , increasing their global footprint and threatening future food security (Bebber et al. 2013). In natural systems, the root-rot fungus Phytophthora cinnamomi is predicted to expand into the Australian alpine region with the reduction of extreme cold events (Burgess et al. 2017).

The active island-wide pathogenic dieback of the dominant alpine species Azorella macquariensis Orchard (Apiaceae, Macquarie cushions) on the natural World Heritage site (NWHS) of Macquarie Island (Bergstrom et al. 2015; Whinam et al. 2014) is now the first occurrence of landscape-scale dieback and large-scale loss of vegetation cover in the subAntarctic (Fig. 1). The trigger for A. macquariensis dieback was hypothesised to be a reduction in plant available water over 17 summer growing seasons, facilitating a secondary pathogenic infection of weakened plants (Bergstrom et al. 2015). A wide range of microbes with pathogenic potential have been identified in association with A. macquariensis, and to date the most likely disease causing agent is considered to be a fungus in the genus Rosellinia (Bergstrom et al. 2015). However, the relationship between climate conditions, pathogen associated symptoms and cushion plant decline remains poorly understood. It is also unclear whether ongoing dieback is driven by conditions that; (i) continue to place the plant under water stress during the summer growing season; (ii) are conducive to pathogens during winter, which coincide with A. macquariensis dormancy; or (iii) promote a combination of these factors. Despite A. macquariensis being physiologically adapted to the small daily fluctuations of stable oceanic island weather (Rolland et al. 2015), similar to the closely related A. selago (le Roux et al. 2005), it is apparently not well adapted to the increased evapotranspiration rates on the island and increased variability in climate (Bergstrom et al. 2015). If water stress alone is driving dieback, this suggests that the highest proportion of dieback would be found in areas of highest abiotic 'stress' on the island. Topographic modelling (i.e. using topography as a proxy for local climate conditions) of A. macquariensis dieback showed latitude (N-S location on island) to be a significant predictor of plant condition. However, it shed little additional light on the possible microscale conditions associated with spatially highly variable patterns of plant decline (Dickson et al. 2019).

Plant distribution and condition responds to fine-scale climate variation (Körner and Hiltbrunner 2018). Therefore, to effectively detect, quantify and monitor change in A. macquariensis and the associated fellfield ecosystem, it is necessary to characterise the finescale spatial variability in the system and progression of disease (see Bland et al. 2018; Sato This article is protected by copyright. All rights reserved 
and Lindenmayer 2018). Similarly, the fine-scale response of plants to climate (Körner and

Hiltbrunner 2018) means it is also important to use relational and abiotic data at relevant spatial and temporal scales to identify relationships between plant vitality and the environment (Lembrechts et al. 2019). This is particularly relevant for alpine systems, where the low-growing flora are strongly influenced by soil and near-ground temperatures, in contrast to the surrounding free-air macro-climate (as generally measured by local weather stations) (Körner and Hiltbrunner 2018; Lembrechts et al. 2019). Macquarie Island is characterised by a tree-less alpine plateau (> $200 \mathrm{~m}$ above sea level, asl), where the lowgrowing (<450 mm high) A. macquariensis is the dominant vascular species (Taylor 1955). Accurate seasonal microclimate measurements on Macquarie Island, at a scale representative of cushion conditions, are needed if the drivers of cushion condition are to be teased apart.

To better understand current dieback progression at a landscape scale and determine future management recommendations, here we test if there is a relationship between fine-scale plant location and cushion condition using a standardised quantification of cushion condition classes and subclasses, along with in situ microclimate measurements. The support for two hypotheses that may also operate additively or synergistically, is then examined. Dieback severity is predicted either by: (i) stress caused by above-ground microclimate conditions (water-stress hypothesis); or (ii) pathogen activity (pathogen hypothesis). If microclimate stress drives condition, A. macquariensis dieback is expected to increase with vapour pressure deficit (VPD) and exposure to drying winds (Bergstrom et al. 2015), or potentially

113 with high fine gravel content (if related to soil water holding capacity) (Whinam et al. 2014).

114 Alternatively, if dieback severity is predicted by pathogen activity then dieback is expected to 115 be high at sites with fewer, less extreme cold days (Burgess et al. 2017) and high humidity

116 (Huber and Gillespie 1992). Building on the coarse-scale climate and cushion condition

117 approach taken by Dickson et al. (2019), here we use microclimate and fine-scale cushion 118 condition classes to further tease apart these putative drivers of dieback. The implications of 119 the results are discussed in the context of the future persistence and management of this 120 critically endangered foundation species under projected climate change. 
Methods

\section{Study system}

124 Macquarie Island $\left(54^{\circ} 30^{\prime} \mathrm{S}, 158^{\circ} 55^{\prime} \mathrm{E}\right)$ is an oceanic sub-Antarctic island covering $123.9 \mathrm{~km}^{2}$

125 (c. $34 \mathrm{~km}$ long, c. $5 \mathrm{~km}$ wide) (Fig. 2), with an undulating alpine plateau at 200 and $433 \mathrm{~m}$ asl.

126 (Selkirk et al. 1990). Historically the local climate has been cool (av. $4.8^{\circ} \mathrm{C}$ ), misty (relative

127 humidity, RH $89 \%$, rainfall $\left.895 \mathrm{~mm} \mathrm{yr}^{-1}\right)$ and windy $\left(9.3 \mathrm{~ms}^{-1}\right)$, with very low daily variation

128 (Selkirk et al. 1990). However, significant change in the regional climate have occurred since

129 the 1970s,including an increase in sunshine hours and the average wind speeds (Bergstrom et

130 al. 2015), and also more frequent and stronger cyclonic events (Adams 2009). The average

131 temperature increased by $0.6^{\circ} \mathrm{C}$ up until the late 1990s (Tweedie and Bergstrom 2000),

132 however, the mean warming trend became increasingly ambiguous from the $1980 \mathrm{~s}$ with a

133 number of cooler years recorded (Pendlebury and Barnes-Keoghan 2007). There has been a

$13435 \%$ increase in annual rainfall between the 1970s and 2010s, which includes a 55\% increase

135 in winter rainfall (Bergstrom et al. 2015). However, the higher number of annual sunshine

136 hours implies that generally the rainfall is more episodic, with larger rainfall events

137 interspersed by longer periods of dry conditions. Together these conditions have resulted in a

138 significant increase in the evapotranspiration rate and a decadal reduction in plant available

139 water during the summer growing season from 1990 to 2008 (Bergstrom et al. 2015).

140 The perennial semi-deciduous endemic Azorella macquariensis ranges in form from discrete

141 cushions, extensive mats, and distinctive terraces (Selkirk 2012). A. macquariensis undergoes

142 winter dormancy ( April - September), with senesced leaves held within the canopy to

143 decompose, before new leaves are produced for the summer growing season ( October -

144 March) (Bergstrom et al. 2015; Taylor 1955). A. macquariensis is a foundation species (see

145 Ellison 2019), defining the structure of fellfield on Macquarie Island (Selkirk 2012), local

146 micro-arthropod diversity, and importantly stabilising ecosystem processes by concentrating

147 soil organic carbon (Bergstrom et al. 2015) and reducing variability and extreme

148 temperatures within its canopy (Taylor 1955). Comparable with other large cushion-forming

149 Azorella species, A. macquariensis is also likely to stabilise moisture content, temperature,

150 and facilitate vascular flora diversity and cover (see Badano et al. 2006; le Roux and

151 McGeoch 2010).

This article is protected by copyright. All rights reserved 
153 Sixty-two sites were established and surveyed between December 2016 and February 2017 across the extent of the plateau (Fig. 2). The survey coincided with the active summer growing season of $\mathrm{A}$. macquariensis. The site locations were determined using a random stratified survey design using four terrain classes and eight geographic units to ensure that the diversity of microclimates were surveyed across the island (method described in detail in

158 Dickson et al. 2019). All sites contained A. macquariensis. Within each $15 \mathrm{~m}$ radius ( 700 $\mathrm{m}^{2}$ ) site, six plots $(2 \mathrm{~m} \times 1 \mathrm{~m})$ were positioned across representative cover and condition of $\mathrm{A}$. macquariensis. Each plot consisted of two immediately adjacent 1 x 1 m quadrats, which were photographed from directly above for image analysis.

\section{Microclimate and terrain variables}

163

Macquarie Island only has one permanent weather station (1.5 $\mathrm{m}$ above the ground). The weather station is considered unrepresentative of the alpine plateau because it is located at sea level on the northern most part of the island (Tweedie and Bergstrom 2000). A fine-scale network of temperature data-loggers were deployed over a 12 month timeframe to capture the influence of terrain and habitat complexity on the free-air microclimate (see Körner and Hiltbrunner 2018; Lembrechts et al. 2019). Data loggers (DS1923 Hygrochon Temperature \& Humidity iButtons, Maxim) were deployed at each site between 15/12/2016 and 27/02/2017 and collected between 24/11/2017 and 02/01/2018. The loggers were secured in a freehanging plastic fob and hung in an upturned light grey PVC container (50 mm diameter). Three slits were cut into each side of the container to improve cross ventilation, while still providing shelter from direct solar radiation and precipitation. The container was fixed 40 $\mathrm{mm}$ above the ground, to replicate the approximate height of A. macquariensis. Data loggers were located on bare ground near to cushion plants to ensure the microclimate measured was experienced by the cushion plants and not the microclimate created by it. Data loggers recorded temperature $\left({ }^{\circ} \mathrm{C}\right)$ and relative humidity $(\mathrm{RH} \%)$, every four hours $(0300,0700,1100$, $1500,1900,2100)$. This measured the free-air microclimate, not the cushion surface temperatures, which are acknowledged to reach much higher temperatures (see BramleyAlves et al. 2014).

Microclimate variables chosen for analysis are those known to affect plant and pathogen stress and growth, including temperature and humidity extremes, vapour pressure deficit (Bergstrom et al. 2015) and number of freezing days (Burgess et al. 2017) (Table 1). Each This article is protected by copyright. All rights reserved 
variable was calculated for the active summer growing season (October - March) of A. macquariensis (see Bergstrom et al. 2015; Taylor 1955).

186 Soil pits were dug to $250 \mathrm{~mm}$ (approximate A. macquariensis root zone) at each site to

187 characterise soil texture and gravel proportions, as potential determinants of A. macquariensis

188 cover and condition. A visual estimate of the proportion of fine gravel $(6-2 \mathrm{~mm})$ was taken

189 (following methods in Sonter et al. 2000). Additional terrain variables that were likely to

190 affect plant stress or growth were derived from the $5 \times 5 \mathrm{~m}$ Macquarie Island digital elevation 191 model (DEM; Brolsma 2008), including northwest and southwest wind shelter (the inverse of

192 wind exposure) (Table 1). Terrain variables were calculated using SAGA (Conrad et al. 2015)

193 and the RSAGA package (Brenning et al. 2018). For dataset, see Dickson et al. (2020).

\section{$194 \quad$ Condition classes}

195 Four A. macquariensis condition classes and eight subclasses were distinguished and 196 described to enable comparison of cushion condition across sites: (1) 'healthy' (subclasses:

197 'smooth', 'uneven', 'Agrostis'); (2) ‘wind-scour'; (3) 'dieback' (subclasses: 'brown', 'olive',

198 'black', 'ablated', 'dieback with Agrostis'); and (4) 'recovery' (Full description see Table

199 S1.1., Appendix S1). The overall 'healthy' and 'dieback' classes were described as the sum

200 of the three and five individual subclasses, respectively. Three dieback progression classes

201 were described to capture the approximate time since pathogenic infection and subsequent

202 senescence of the leaves and canopy. These were defined as: 'active' dieback ('brown', $\leq$ one

203 year since infection), 'thinning' dieback ('olive' + 'dieback with Agrostis', approximately

204 one to two years since infection) and 'advanced' dieback ('black' + 'ablated', $\geq$ two years

205 since infection) (Table S1.1., Appendix S1).

206 The total A. macquariensis cover and the proportion of each subclass was delineated for each

207 quadrat $\left(1 \mathrm{~m}^{2}\right)$ and subsequently measured in ImageJ $1.52 \mathrm{i}$ (Rueden et al. 2017). The

208 proportion of each condition class per site $\left(12 \times 1 \mathrm{~m}^{2}\right.$ quadrats $)$ was calculated as the total of

209 the class in each plot divided by cover. The mean $( \pm$ s.e., $\mathrm{n}=12)$ plot data was used for all

210 subsequent cover and dieback analyses to address the data distribution within the highly

211 spatially variable species. The number of cushions were not counted, as discrete cushions and

212 mats can be composed of multiple individuals (Cerfonteyn et al. 2011). For detailed methods

213 see Appendix S1 and dataset availability see Dickson et al. (2020). 


\section{Regional condition and microclimate}

215 The island was divided into three equal latitudinal regions, northern, central, and southern, in

216 line with natural breaks in geology and elevation. To determine whether there was a

217 relationship between the proportion of A. macquariensis within each cushion condition class

218 and latitudinal regions on the island a non-parametric Kruskal-Wallis one-way analysis of

219 variance was used. The average proportion of A. macquariensis within each condition class

220 (\%) was described as a function of location (northern, central and southern). A post hoc

221 Dunn's test of multiple comparisons with Holm's adjusted p-values (Dinno and Dinno 2017)

222 was used to determine differences between regions for each of the three dieback progression

223 classes.

224 To determine if there was a significant relationship between summer growing season (Oct -

225 Mar) microclimate and latitudinal regions, a one-way analysis of variance model (ANOVA)

226 and post-hoc Tukey's Honest Significant Difference test was used. Each of the six summer

227 microclimate variables (Table 1) were tested against the three equal latitudinal regions of the

228 island, northern, central and southern. To meet model assumptions summer vapour pressure

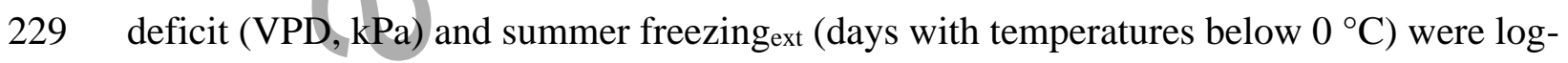

230 transformed, and summer humidity ext $\left(95^{\text {th }}\right.$ percentile of the mean daily relative humidity)

231 was tested using a non-parametric Kruskal-Wallis, with a Dunn's test of multiple

232 comparisons using Holm's adjusted p-values.

233 Latitude was hypothesised to be a proxy for macro-climate by Dickson et al. (2019), although

234 latitude is also correlated with elevation $(\mathrm{r}=0.31)$. Elevation has a lapse rate of $-0.71^{\circ} \mathrm{C}$

$235100 \mathrm{~m}^{-1}$ on the island, which increases non-linearly (Tweedie and Bergstrom 2000). To

236 determine if a latitudinal temperature gradient occurred independent of elevation, the

237 relationship between microclimate temperature and the covariates latitude and elevation was

238 modelled using a general linear model (similar to Córdova et al. (2016), i.e temperature =

239 latitude + elevation). Models were run for the summer (Oct - Mar) and winter (Apr - Sep)

240 seasons for each of the different temperature variables to capture aspects of daily variation

241 (i.e. the daily mean, $\mathrm{T}_{\text {mean; }}$ mean daily minimum, $\mathrm{T}_{\min }$; and mean daily maximum, $\mathrm{T}_{\max }$ for

242 both seasons). Northing was used as the measurement for latitude to be able to directly relate

243 the rate of change of temperature in kilometres down the island. 
245 The variables used to model the relationship between in situ summer microclimate variables and the proportion of A. macquariensis cover affected by dieback across Macquarie Island included, (i) variables previously suggested to stress the plants or promote pathogen virulence and extent, and (ii) relevant terrain variables from Dickson et al. (2019) (wind shelter and soil gravel content). Azorella macquariensis takes up most water through fine adventitious roots within the canopy (Bergstrom et al. 2015), sourcing water from rainfall and low cloud that condenses on the leaves. Therefore other potential proxies for atmospheric water, such as cloud cover, cloud height and wind direction (moisture), were considered, however, they would necessarily be topographically-derived and subject to the limitations identified in Dickson et al. (2019). Soil moisture is an important determinant of plant water stress, which we partially account for by incorporating gravel content in the models as a proxy for water holding capacity. However, given the reliance of A. macquariensis on water sourced through fine adventitious canopy roots (Bergstrom et al. 2015) and the lack of relationship between cushion dieback and topographically-derived wetness index (Dickson et al. 2015), other soil moisture variables were not included in the model. To reduce collinearity, microclimate variable choice was informed by an exploratory principal component analysis (PCA, prcomp, in 'stats' package). Summer (growing season) variables included in the models represented the three main axes of the PCA (i) freezing ext, representing coldext, (ii) humidityext representing dryext (negative relationship), and (iii) VPD representing hotext and affecting water availability.

The effect of microclimate on island-wide A. macquariensis dieback was modelled as the proportion of Dieback class as a function of (i) summer microclimate conditions that may affect pathogen activity, including freezing ext $_{\text {and humidity }}$ (\%) (ii) variables that are likely to influence plant available water, including summer VPD (Pa), Fine_Gravel (\%) and Wind_Shelternw (no units) and (iii) the covariate A. macquariensis cover (Cover,\%). No strong non-linear relationships between Dieback and predictor variables were identified in preliminary analysis using Generalized Additive Models (GAM; family = beta, link = logit) with smoothing applied to each of the predictor variables (mgcv; Wood 2017). Consequently, no polynomial terms were included. Dieback $(0-1)$ was modelled using a beta regression model with a logit link function (betareg; Zeileis et al. 2016). The variance inflation factors (VIFs) (Barton and Barton 2018) of the model were low $(<2.6)$, showing little collinearity. 
There was no spatial autocorrelation over the spatial lag of zero to $22 \mathrm{~km}$ on a $34 \mathrm{~km}$ island (global Moran's I; Bivand et al. 2017).

278 To enable direct comparison of the direction and effect size of each predictor variable,

279 predictor variables were standardised. The response curve was plotted for each predictor 280 variable within the surveyed range, holding the remaining variables at the $50^{\text {th }}$ percentile 281 value, to explore the response of dieback under varying microclimate and terrain conditions.

282 The rows of data were resampled 1000 times to produce bootstrapped $95 \%$ confidence 283 intervals around the mean using the lm.boot function from the 'simpleboot' (Peng 2019) in R.

284 To further explore the relationship between dieback and the two significant variables within the beta regression dieback model, a linear regression model was run to determine if there was a significant difference between the slopes for the levels of cover affected by dieback for cushions with $<5 \%$ dieback and those with $\geq 5 \%$ dieback. The model was described as

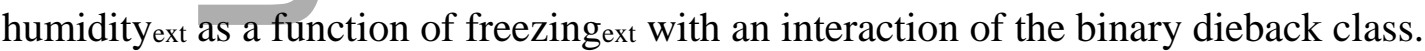

All analyses were performed using RStudio Desktop 1.2.1335 using R for Windows 3.6.0 (R Core Team 2019).

291

292

\section{Results}

\section{Regional variation in microclimate}

294 Of the six summer microclimate variables quantifying extremes $\left(5^{\text {th }}\right.$ or $95^{\text {th }}$ percentile) recorded during the growing season and selected for inclusion within models, freezing ext $\left(\mathrm{F}_{2,59}=17.13, \mathrm{p}<0.001\right)$ and coldext $\left(\mathrm{F}_{2,59}=6.50, \mathrm{p}<0.01\right)$ differed significantly between

297 the three regions (Fig. 3). The number of summer southern freezing ext $_{\text {days }}$ was significantly 298 higher than the number of northern $(\mathrm{p}<0.001)$ and central $(\mathrm{p}<0.001)$ freezing days (Fig. 3), however, there was no significant difference between the north and centre. Similarly, summer

300 cold $_{\text {ext }}(r=-0.79$ with freezing ext $)$ was lower in the south than both the centre and north of the 301 island ( $\mathrm{p}=0.002, \mathrm{p}=0.03$, respectively; Fig. 3). Mean annual, summer growing season (Oct 302 - Mar) and winter senescence season (Apr - Sep) microclimate statistics are presented in 303 Table S2.1, Appendix S2.

304 There was a significant temperature lapse and latitudinal gradient for $\mathrm{T}_{\operatorname{mean}}, \mathrm{T}_{\min }$, and $\mathrm{T}_{\max }$.for all three time periods (annual, summer growing season and winter senescence season). All This article is protected by copyright. All rights reserved 
306

307

308

309

310

311

312

313

314

315

316

317

318

319

320

321

322

323

324

325

326

327

328

329

330

331

332

333

334

335

336

three temperature variables were significantly lower at high elevation sites for all three time periods and significantly colder towards the south for all variables but annual and summer $\mathrm{T}_{\max }$ (Table S2.2, Appendix S2). The goodness-of-fit was highest in winter (adj- $\mathrm{R}^{2}=0.87-$ 0.95 ) and lowest in the growing season (adj- $\mathrm{R}^{2}=0.42-0.69$ ). The elevational temperature lapse was highest for $\mathrm{T}_{\max }\left(-1.14 \pm 0.19^{\circ} \mathrm{C} 100 \mathrm{~m}^{-1}\right)$ and lowest for $\mathrm{T}_{\min }\left(-0.58 \pm 0.06{ }^{\circ} \mathrm{C} 100\right.$ $\mathrm{m}^{-1}$ ) over the summer growing season (Table S2.2; Appendix S2). The latitudinal temperature gradient down the full extent of the island was highest during the summer growing season (change in $\mathrm{T}_{\text {mean }}$ north to south $=-0.49 \pm 0.15^{\circ} \mathrm{C}$ ) and lowest during winter (change in $\mathrm{T}_{\text {min }}$ north to south $\left.=-0.12 \pm 0.06^{\circ} \mathrm{C}\right)($ Table S2.1, Appendix S2).

\section{Cushion condition}

Approximately two-thirds $(67.8 \%, \pm 3.19$ s.e.) of the island-wide cushion cover was Healthy, with the highest proportion occurring in the south (Table S1.2., Appendix S1). Wind-scour and Recovery classes were very minor components of cushion cover $(<2 \%)$; details are presented in detail in Appendix S1.

Across the island almost one third $(29.66 \%, \pm 3.08$ s.e.) of cushion cover was affected by Dieback (Table 2). It differed significantly between the regions $\left(X^{2}=6.67, d f=2, p=0.04\right)$, with more in the north than the central $(\mathrm{z}=-2.20, \mathrm{p}=0.03)$ or the south $(\mathrm{z}=2.29, \mathrm{p}=0.04$; centre also $>$ south, $\mathrm{z}=3.97, \mathrm{p}=<0.001$; Fig. S1.1. Appendix S1). Dieback was 32\% higher in the north $(47.3 \% \pm 5.84)$ than in the south $(15.2 \% \pm 4.62$; Table S1.2., Appendix S1).

Azorella macquariensis affected by Dieback (\%) was predicted by the summer microclimate variables, humidity ext $_{\text {and freezing }}$ ext $_{(\text {Pseudo- }}{ }^{2}=0.27$, Fig. 4a, Table S2.3a, Appendix S2). Dieback was higher in sites with fewer freezing ext days and higher humidityext (Fig. 4a. and Fig. S2.1. Appendix S2). Variables related to water-stress (NW wind shelter, fine gravel content, summer $\mathrm{VPD}$ ) and the co-variate A. macquariensis cover were not significant in the dieback model (Fig. 4a, Table S2.3a, Appendix S2). The interaction between summer freezing ${ }_{\text {ext }}$ and the presence of the healthy cushions ( $<5 \%$ dieback) was significant (Table S2.3b., Appendix S2, p = 0.002), revealing a comparatively narrow band of conditions between summer humidityext and summer freezing ext $_{\text {whe }}$ wealthy cushions ( $<5 \%$ dieback) were present on the island (Fig. 4b). Healthy cushions were present at sites with low

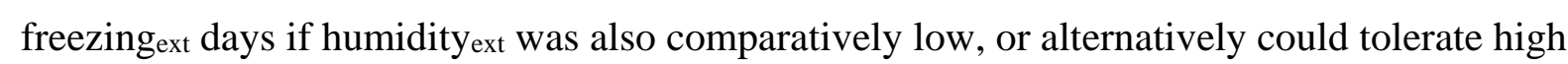
humidityext if freezingext days were also high during the summer season (Fig. 4b).

This article is protected by copyright. All rights reserved 
337 Advanced dieback affected the most cushion cover of the three progression classes $(13.72 \% \pm$ 3382.50 s.e., Fig. 2, Table S1.2. Appendix S1), differing between all regions $\left(X^{2}=22.19\right.$, df $=2$, $339 \mathrm{p}<0.001$; north $>$ centre $\mathrm{z}=-3.12, \mathrm{p}<0.01$; north $>$ south $\mathrm{z}=4.70, \mathrm{p}<0.001$; centre > 340 south $\mathrm{z}=2.17, \mathrm{p}=0.03$; Fig. 2, Table S1.2. Appendix S1). Advanced dieback was

341 considerably higher in the north, increasing from $2.5 \%$ ( \pm 0.84 s.e.) cover in the south to $34.4 \%$

342 ( \pm 6.82 s.e.) in the north (Fig. 2, Table S1.2. Appendix S1). Island-wide Thinning affected $34312.96 \%( \pm 1.83$ s.e. $)$ of cushion cover. The least common progression class, Active dieback, 344 affected $<3.0 \%$ ( \pm 0.77 s.e. $)$ of cushion cover island-wide, highest in the centre $(5.3 \% \pm 1.5$ 345 s.e.) and lowest in the south ( $0.9 \% \pm 0.47$ s.e.) (Table S1.2. Appendix S1, Fig. 2). Neither 346 Active nor Thinning dieback varied significantly between regions $\left(X^{2}=4.40, \mathrm{df}=2, \mathrm{p}=0.11\right.$; $347 \mathrm{X}^{2}=1.71, \mathrm{p}=0.43, \mathrm{df}=2$ respectively; Fig. 2 ).

\section{Discussion}

349 Azorella macquariensis dieback remains active across Macquarie Island, with dieback 350 condition classes affecting almost one third of the critically endangered cushion cover islandwide. A north-south gradient in cushion condition is present, where advanced dieback was highest in the north, active dieback in the centre, and the extensive southern populations were healthiest. Azorella macquariensis dieback extent was best explained by the pathogen

354 hypothesis, where dieback was correlated with microclimate conditions conducive to disease

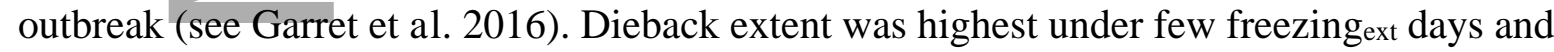
high humidity ext. This result, in combination with new, island-wide microclimate data and the significant relationship between location and condition, provides a plausible explanation for the low levels of dieback in the extensive southern populations on the island. However, disease outbreaks require not only the environmental conditions to be conducive to the pathogen, but also a susceptible host and/or more virulent pathogen (see Garrett et al. 2016). Therefore, while the summer growing season drought-like conditions (Bergstrom et al. 2015) may have triggered the initial outbreak of dieback across the island, it now appears the effects of wetter (most pronounced in winter), warmer seasons favours pathogen infection and associated dieback. This, in combined with a warmer, more variable summer growing season is most likely to be driving the ongoing A. macquariensis dieback across Macquarie Island. classes has provided a more nuanced understanding of the drivers of dieback, required to determine temporal trends and estimate the rate of cushion cover loss across the island. The 
recent decline in cushion condition was represented by three dieback progression classes, capturing the high variation in cushion decline from individual cushion to island-wide scales. Active dieback is ongoing across all regions and at a rate similar to the same dieback stage documented in 2010, then referred to as 'yellow' damage describing the leaf chlorosis (loss of green colouration) following senescence, natural or pathogenic (Whinam et al. 2014). Very low-levels of cushion recovery were recorded across the island, with the highest in the north of the island in areas of advanced dieback (Appendix S1). However, the repeated 'waves' of dieback at previously infected areas (see Dickson et al. 2019), strongly suggest that there may not be the capacity for the species to regain its previous cover, warning of an impending structural change in this landscape.

The dieback progression classes confirm that there is a latitudinal gradient in cushion condition down the island, as hypothesised by Dickson et al. (2019). Old advanced dieback and associated cover loss are concentrated in the north of Macquarie Island, while active dieback is highest in the centre and cushions are healthiest in the south (Appendix S1). The latitudinal distribution of dieback progression classes appear indicative of a temporal dieback progression down the island. However, dieback was recorded across the extent of the island from the first season of observation in 2008/09 (Bergstrom et al. 2015) and the low proportion of southern cushions affected by dieback has remained relatively constant over time (Dickson et al. 2019). This suggests rather than spreading from a northern infection point, dieback progression or pathogen virulence is higher in the north under more suitable conditions.

The decadal reduction in summer plant available water was previously considered the likely main driver of A. macquariensis decline, with weakened cushions more susceptible to secondary pathogenic infection (Bergstrom et al. 2015). However, here cushion dieback was related to microclimate extremes, with more dieback at sites experiencing higher humidityext and fewer freezingext days. This pattern supports the hypothesis that dieback extent is now better explained by pathogen ecology. Variables likely to affect plant water stress (VPD highly correlated with hotext, wind exposure - inverse of wind shelter and soil gravel content) were not important to dieback in the model. Healthy cushions $(\leq 5 \%$ dieback $)$ occurred within a narrow band of freezingext and humidityext values. Healthy condition was maintained with high freezing ext $_{\text {days despite very high humidity }}$ ext, or conversely, cushions could

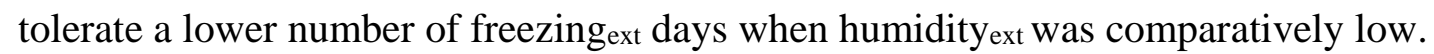


Together these results support the pathogen hypothesis, where dieback is currently predicted by pathogen ecology, rather than solely by water stress.

403 High humidity is known to promote plant pathogens, while freezing days suppress them, with responses varying amongst taxonomic groups (Chakraborty 2013; Garrett et al. 2016; Harvell et al. 2002). For example, water moulds (Oomycetes) and fungal pathogens are both generally promoted under warmer, wetter climates (Homet et al. 2019; Welsh et al. 2014), making them likely candidates for the pathogens affecting cushion dieback, potentially acting individually or in consortium with multiple taxa. Leaf saturation is important in disease outbreaks (see Huber and Gillespie 1992). This is currently best represented at a site-level by relative humidity $(\mathrm{RH})$, as a proxy for atmospheric water. Macquarie Island has a very high daily mean humidity (data loggers annual RH daily mean $95.75 \% \pm 1.05$; Table S2.1, Appendix S2), however, there are fluctuations between and within sites (data logger RH full range $25.99-100 \%$ ). Therefore, while the range in average daily humidity ext quantified across sites on Macquarie Island was $2.27 \%$, as with many other climate averages, this range should be interpreted in terms of its relative difference. Cumulatively over time, this variation in extreme humidity may well represent a biologically significant shift in humidity. Given the importance of extreme humidity in the model, empirical soil moisture data and soil moisture modelling are worth future investment to better understand the relationship between soil moisture and atmospheric humidity, and its relationships with plant health and pathogen distribution on the island.

Disease is unlikely to be responding in isolation or as a straightforward linear relationship with one or several different drivers, rather as a response to highly complex interactions between climate, environment and pathogen variables (Chakraborty et al. 2000; Rohr et al. 2011). The ability of plants to resist and recover from novel pathogens can be further compromised when faced with a combination of novel extreme events such as drought, flooding, and frost (Stenlid and Oliva 2016). Despite plants no-longer appearing droughtstressed (DMB pers. obs.), it is likely the significantly higher maximum and extreme maximum temperatures during the growing season (Table S3.1., Appendix S3) are contributing to background stress. It therefore seems increasingly likely the prolonged drought-like conditions may have triggered the emergence of disease, and the wetter, warmer winters maintain the pathogen, which continues to affect cushions weakened by an increasingly warm, variable growing season. 
433 The landscape-scale distribution of dieback is, at least partially, driven by macro-scale 434 weather conditions. The southern plateau is higher in elevation and regularly shrouded in 435 cloud (Selkirk et al. 1990). Therefore, it was thought cooler temperatures, potentially with 436 more available atmospheric water, explained the extensive and healthier southern A. 437 macquariensis populations (Dickson et al. 2019). The microclimate data presented here 438 confirm the southern region is significantly colder with more freezing days and there is a 439 significant negative temperature gradient down the island in addition to the expected reduced 440 temperatures at higher elevation. However, the availability of atmospheric water (represented 441 here by relative humidity) was comparatively stable down the island. This suggests the 442 latitudinal gradients of cushion condition shown here, may be driven by the prevalence of 443 freezing days rather than available atmospheric water. It appears therefore, the extreme cold 444 temperatures in the south have provided some refuge from the rapidly progressing and 445 extensive dieback (see Burgess et al. 2017; Harvell et al. 2002; Marçais et al. 1996). The 446 average number of freezing days recorded at the Bureau of Meteorology weather station in 447 the north of the island have remained constant since 1948 (Table S3.1., Appendix S3). It is 448 unclear whether this general trend of stable cold temperatures can be extrapolated across the 449 island to provide further insight into disease emergence, as there is no southern weather 450 station. Regardless, under the current climate trajectory it is unclear how long these cold 451 refugia will persist.

452 The confirmation of southern refugia reinforces the value of maintaining the three existing 453 Azorella special management areas (SMAs) in the south of the island, which still contain 454 some the most extensive and healthiest cushion 'mats' on the island. The SMAs reduce 455 expeditioner entry into the area and require soil hygiene procedures, both well accepted 456 management actions for landscape disease containment (Monks et al. 2019). Unfortunately 457 cushion dieback is present in the SMAs at low levels, however, while the pathogens and 458 control measures remain unknown, the SMAs remain the best available option for reducing 459 any additional movement of the pathogens or disturbance in the area (see Bergstrom et al. 460 2015). Bolder management actions are required to stop the ongoing decline of this endemic 461 foundation species, commencing with the identification of the pathogens, potential disease 462 containment or control options, and propagation techniques. 


\section{Conclusions}

464 Changes in the regional climate towards a system that is warmer and more variable in the summer, and wetter and warmer in winter appear to be facilitating the ongoing dieback of Azorella macquariensis across Macquarie Island. These changes are both directly and indirectly threatening A. macquariensis' survival, by weakening the plant and increasing the virulence of an associated pathogen, respectively. Similar to other ecosystems, it appears that the climate-driven change in the secondary biotic interaction between A. macquariensis and the pathogen is posing the greatest threat to the cushions (see Cahill et al. 2013; Ockendon et al. 2014). Under current climate conditions, where Macquarie Island is more variable, warmer and wetter than historically experienced, dieback is likely to persist. The monitoring of microclimate and use of refined cushion condition classes to assess trends in plant condition are considered a priority to be able to identify the rate of regime change and to appropriately direct management effort. The distributional extent of this iconic foundation species, and its role in the diversity and functioning of the broader fellfield ecosystem are central to the natural value of Macquarie Island. The decline in this species in response to a changed regional climate emphasises the need to track and better manage shifting baselines, including within well conserved Natural World Heritage Sites. The extent of cushion dieback and resultant loss of cover signals a potential regime shift on the Island's fellfield plateau, and possibly more generally across sub-Antarctic fellfield ecosystems. Early detection of change within these remote high latitude systems provides the best ability to successfully address future climate-driven threats and maintain their unique character.

\section{Species Nomenclature}

485 Azorella macquariensis Orchard, Apiaceae, Macquarie cushions

\section{Acknowledgements}

487 We thank Dr Patricia Selkirk and Dr Grant Duffy for constructive discussions about the 488 manuscript, and John Burgess and Rowena Hannaford for assistance with field work. We

489 thank the handling editor and reviewers for their comments on the manuscript. This study

490 was funded by an Australian Government, Australian Antarctic Science Program Grant 491 (\#4312) and an Australian Government Research Training Program (RTP) Scholarship, the

492 Holsworth Wildlife Research Endowment and The Ecological Society of Australia, and the

493 Denis and Maisie Carr Award.

This article is protected by copyright. All rights reserved 


\section{References}

496

Adams N. (2009) Climate trends at Macquarie Island and expectations of future climate change in the sub-Antarctic. Pap. Proc. R. Soc. Tasman. 143, 1-8.

498 Allan J. R., Venter O., Maxwell S., et al. (2017) Recent increases in human pressure and 499 forest loss threaten many Natural World Heritage Sites. Biological Conservation 206, 47-55.

500 Allen R. G., Pereira L. S., Raes D. \& Smith M. (1998) Crop evapotranspiration-Guidelines

501 for computing crop water requirements-FAO Irrigation and drainage paper 56. Fao, Rome 300, D05109.

503 Anderson P. K., Cunningham A. A., Patel N. G., et al. (2004) Emerging infectious diseases

504 of plants: pathogen pollution, climate change and agrotechnology drivers. Trends in Ecology

505 \& Evolution 19, 535-44.

506 Badano E. I., Jones C. G., Cavieres L. A. \& Wright J. P. (2006) Assessing impacts of

507 ecosystem engineers on community organization: a general approach illustrated by effects of 508 a high-Andean cushion plant. Oikos 115, 369-85.

509 Barton K. \& Barton M. K. (2018) Package 'MuMIn': Multi-Model Inference. Version: 1.40.4.

510 CRAN, https://CRAN.R-project.org/package=MuMIn.

511 Bebber D. P., Ramotowski M. A. T. \& Gurr S. J. (2013) Crop pests and pathogens move

512 polewards in a warming world. Nat. Clim. Change 3, 985.

513 Bergstrom D. M., Bricher P. K., Raymond B., et al. (2015) Rapid collapse of a sub-Antarctic

514 alpine ecosystem: the role of climate and pathogens. J. Appl. Ecol. 52, 774-83.

515 Bivand R., Altman M., Anselin L., et al. (2017) Package 'spdep': Spatial Dependence:

516 Weighting Schemes, Statistics and Models. Version 0.7-4. . CRAN, https://CRAN.R-

517 project.org/package=spdep.

518 Bland L. M., Rowland J. A., Regan T. J., et al. (2018) Developing a standardized definition

519 of ecosystem collapse for risk assessment. Front. Ecol. Environ. 16, 29-36.

520 Boyd I. L., Freer-Smith P. H., Gilligan C. A. \& Godfray H. C. J. (2013) The Consequence of

521 Tree Pests and Diseases for Ecosystem Services. Science 342, 1235773.

522 Bramley-Alves J., King D. H., Robinson S. A. \& Miller R. E. (2014) Dominating the

523 Antarctic Environment: Bryophytes in a Time of Change. In: Photosynthesis in Bryophytes

524 and Early Land Plants (eds D. T. Hanson and S. K. Rice) pp. 309-24. Springer Netherlands, 525 Dordrecht. 
526 Brenning A., Bangs D., Becker M., Schratz P. \& Polakowski F. (2018) Package 'RSAGA',

527 Version 1.3.0. https://github.com/r-spatial/RSAGA.

528 Brolsma H. (2008) Macquarie Island AIRSAR DEM (Digital Elevation Model).

529 http://data.aad.gov.au/aadc/metadata/.

530 Burgess T. I., Scott J. K., Mcdougall K. L., et al. (2017) Current and projected global

531 distribution of Phytophthora cinnamomi, one of the world's worst plant pathogens. Global

532 Change Biol. 23, 1661-74.

533 Cahill A. E., Aiello-Lammens M. E., Fisher-Reid M. C., et al. (2013) How does climate

534 change cause extinction? Proc. R. Soc. B. 280, 20121890.

535 Cerfonteyn M. E., Le Roux P. C., Van Vuuren B. J. \& Born C. (2011) Cryptic spatial

536 aggregation of the cushion plant Azorella selago (Apiaceae) revealed by a multilocus

537 molecular approach suggests frequent intraspecific facilitation under sub-Antarctic conditions.

538 American Journal of Botany 98, 909-14.

539 Chakraborty S. (2013) Migrate or evolve: options for plant pathogens under climate change.

540 Global Change Biol. 19, 1985-2000.

541 Chakraborty S., Tiedemann A. V. \& Teng P. S. (2000) Climate change: potential impact on

542 plant diseases. Enyiron. Pollut. 108, 317-26.

543 Cohen J. M., Civitello D. J., Venesky M. D., McMahon T. A. \& Rohr J. R. (2019) An

544 interaction between climate change and infectious disease drove widespread amphibian

545 declines. Global Change Biol. 25, 927-37.

546 Conrad O., Bechtel B., Bock M., et al. (2015) System for automated geoscientific analyses

547 (SAGA) v. 2.1. 4. Geoscientific Model Development 8, 1991-2007.

548 Córdova M., Célleri R., Shellito C. J., et al. (2016) Near-Surface Air Temperature Lapse Rate

549 Over Complex Terrain in the Southern Ecuadorian Andes: Implications for Temperature

550 Mapping. Arct. Antarct. Alp. Res. 48, 673-84.

551 Dickson C. R., Baker D. J., Bergstrom D. M., et al. (2019) Spatial variation in the ongoing

552 and widespread decline of keystone plant species. Austral Ecol. 44, 891-905.

553 Dickson C. R., McGeoch M. A., Bergstrom D. M., Whinam J. \& Baker D. J. (2020) Fine-

554 scale Azorella macquariensis condition and site microclimate extremes data from Macquarie

555 Island, v1. (ed Australian Antarctic Data Centre -

556 http://dx.doi.org/doi:10.26179/5e71aba2c846a ).

557 Dinno A. \& Dinno M. A. (2017) Package 'dunn.test'. Version 1.3.5., https://cran.r-

558 project.org/web/packages/dunn.test/dunn.test.pdf.

This article is protected by copyright. All rights reserved 
Ellison A. M. (2019) Foundation Species, Non-trophic Interactions, and the Value of Being

560 Common. iScience 13, 254-68.

561 Garrett K. A., Nita M., De Wolf E. D., et al. (2016) Chapter 21 - Plant Pathogens as

562 Indicators of Climate Change. In: Climate Change (Second Edition) (ed T. M. Letcher) pp.

563 325-38. Elsevier, Boston.

564 Harvell C. D., Mitchell C. E., Ward J. R., et al. (2002) Climate Warming and Disease Risks

565 for Terrestrial and Marine Biota. Science 296, 2158-62.

566 Hoberg E. P. \& Brooks D. R. (2015) Evolution in action: climate change, biodiversity

567 dynamics and emerging infectious disease. Philosophical Transactions of the Royal Society B:

568 Biological Sciences 370, 20130553.

569 Hoffmann A. A., Rymer P. D., Byrne M., et al. (2019) Impacts of recent climate change on

570 terrestrial flora and fauna: Some emerging Australian examples. Austral Ecol. 44, 3-27.

571 Homet P., González M., Matías L., et al. (2019) Exploring interactive effects of climate

572 change and exotic pathogens on Quercus suber performance: Damage caused by

573 Phytophthora cinnamomi varies across contrasting scenarios of soil moisture. Agricultural

574 and Forest Meteorology 276-277, 107605.

575 Huber L. \& Gillespie T. J. (1992) Modeling Leaf Wetness in Relation to Plant Disease

576 Epidemiology. Annu. Rev. Phytopathol. 30, 553-77.

577 Körner C. \& Hiltbrunner E. (2018) The 90 ways to describe plant temperature. Perspect.

578 Plant Ecol. Evol. Syst. 30, 16-21.

579 le Roux P. C. \& McGeoch M. A. (2010) Interaction intensity and importance along two stress

580 gradients: adding shape to the stress-gradient hypothesis. Oecologia 162, 733-45.

581 le Roux P. C., McGeoch M. A., Nyakatya M. J. \& Chown S. L. (2005) Effects of a short-term

582 climate change experiment on a sub-Antarctic keystone plant species. Global Change Biol.

583 11, 1628-39.

584 Lembrechts J. J., Lenoir J., Roth N., et al. (2019) Comparing temperature data sources for use

585 in species distribution models: From in-situ logging to remote sensing. Global Ecol. Biogeogr.

$586 \quad 28,1578-96$.

587 Marçais B., Dupuis F. \& Desprez-Loustau M. (1996) Modelling the influence of winter frosts

588 on the development of the stem canker of red oak, caused by Phytophthora cinnamomi. Ann.

589 For. Sci. 53, 369-82.

590 Monks L., Barrett S., Beecham B., et al. (2019) Recovery of threatened plant species and

591 their habitats in the biodiversity hotspot of the Southwest Australian Floristic Region. Plant

592 Diversity 41, 59-74.

This article is protected by copyright. All rights reserved 
593 Ockendon N., Baker D. J., Carr J. A., et al. (2014) Mechanisms underpinning climatic

594 impacts on natural populations: altered species interactions are more important than direct

595 effects. Global Change Biol. 20, 2221-29.

596 Pauchard A., Milbau A., Albihn A., et al. (2016) Non-native and native organisms moving

597 into high elevation and high latitude ecosystems in an era of climate change: new challenges

598 for ecology and conservation. Biological Invasions 18, 345-53.

599 Pendlebury S. F. \& Barnes-Keoghan I. P. (2007) Climate and climate change in the sub-

600 Antarctic. Pap. Proc. R. Soc. Tasman. 141, 67-82.

601 Peng R. D. (2019) simpleboot: Simple Bootstrap Routines. CRAN, https://CRAN.R-

602 project.org/package=simpleboot.

603 Preisler H. K., Hicke J. A., Ager A. A. \& Hayes J. L. (2012) Climate and weather influences

604 on spatial temporal patterns of mountain pine beetle populations in Washington and Oregon.

605 Ecology 93, 2421-34.

606 R Core Team. (2019) R: A Language and Environment for Statistical Computing. R

607 Foundation for Statistical Computing, Vienna, Austria. https://www.R-project.org/.

608 Rohr J. R., Dobson A. P., Johnson P. T. J., et al. (2011) Frontiers in climate change-disease

609 research. Trends in Ecology \& Evolution 26, 270-77.

610 Rolland V., Bergstrom D. M., Lenne T., et al. (2015) Easy Come, Easy Go: Capillary Forces

611 Enable Rapid Refilling of Embolized Primary Xylem Vessels. Plant Physiol. 168, 1636-47.

612 Rueden C. T., Schindelin J., Hiner M. C., et al. (2017) ImageJ2: ImageJ for the next

613 generation of scientific image data. BMC Bioinformatics 18, 529.

614 Sato C. F. \& Lindenmayer D. B. (2018) Meeting the Global Ecosystem Collapse Challenge.

615 Conservation Letters 11, e12348.

616 Selkirk P. M. (2012) Plateau Vegetation On Sub-Antarctic Macquarie Island. Pap. Proc. R.

617 Soc. Tasman. 146, 71-79.

618 Selkirk P. M., Seppelt R. D. \& Selkirk D. R. (1990) Subantarctic Macquarie Island:

619 environment and biology. Cambridge Press University Press, Cambridge.

620 Sicard A., Zeilinger A. R., Vanhove M., et al. (2018) Xylella fastidiosa: Insights into an

621 Emerging Plant Pathogen. Annu. Rev. Phytopathol. 56, 181-202.

622 Sonter R. O., Semple W. S. \& Lawrie J. W. (2000) Soils, vegetation and land use. In: Soils:

623 their properties and management (eds P. E. Charman and B. W. Murphy) pp. 271-86. Oxford

624 University Press, Melbourne.

This article is protected by copyright. All rights reserved 
625 Stenlid J. \& Oliva J. (2016) Phenotypic interactions between tree hosts and invasive forest

626 pathogens in the light of globalization and climate change. Philosophical Transactions of the

627 Royal Society B: Biological Sciences 371, 20150455.

628 Taylor B. W. (1955) The flora, vegetation and soils of Macquarie Island. In: ANARE Reports,

629 Series B, 11 pp. 1-192. Australian Antarctic Division, Melbourne.

630 Tweedie C. E. \& Bergstrom D. M. (2000) A climate change scenario for surface air

631 temperature at subantarctic Macquarie Island (ed.). In: Antarctic Ecosystems: Models for

632 Wider Understanding (eds W. Davison, C. Howard-Jones and P. Broady) pp. 272-81.

633 Canterbury University Press, Canterbury.

634 Welsh C., Lewis K. J. \& Woods A. J. (2014) Regional outbreak dynamics of Dothistroma

635 needle blight linked to weather patterns in British Columbia, Canada. Canadian Journal of

636 Forest Research 44, 212-19.

637 Whinam J., Abdul-Rahman J. A., Visoiu M., di Folco M. B. F. \& Kirkpatrick J. B. (2014)

638 Spatial and temporal variation in damage and dieback in a threatened subantarctic cushion

639 species. Aust. J. Bot. 62, 10-21.

640 Wood S. N. (2017) Generalized additive models: an introduction with R. Chapman and

641 Hall/CRC, New York.

642 Zeileis A., Cribari-Neto F., Gruen B., et al. (2016) betareg: Beta Regression. Version 3.1-0.

643 https://CRAN.R-project.org/package=betareg

644

645 Supporting Information

646 Appendix S1: Extended methods and description of Azorella macquariensis condition

647 classes with associated summary statistics. Additional analysis provided of the Healthy,

648 Wind-scour and Recovery condition classes.

649 Appendix S2: Supplementary abiotic and biotic data, and modelled response of Azorella 650 macquariensis condition to microclimate and terrain variables.

651 Appendix S3: Analysis of long-term trends of temperature variables at Macquarie Island 652 Bureau of Meteorology weather station between 1948 and 2018. 
Table 1. Microclimate and terrain variables used in Azorella macquariensis condition and microclimate model for Macquarie Island. All microclimate variables were calculated from site data loggers for the summer growing (October - March) season.

\begin{tabular}{|c|c|c|}
\hline Variable & Abbreviation & Description \\
\hline Extreme cold & Cold $_{\mathrm{ext}}$ & Mean daily temperature $5^{\text {th }}$ percentile. \\
\hline Extreme ho & Hot $_{\text {ext }}$ & Mean daily temperature $95^{\text {th }}$ percentile. \\
\hline Extreme dry & Dryext $_{\text {ext }}$ & Mean daily relative humidity $5^{\text {th }}$ percentile. \\
\hline Extreme humidity & Humidity $_{\mathrm{ext}}$ & Mean daily relative humidity $95^{\text {th }}$ percentile. \\
\hline Vapour pressure deficit & VPD & $\begin{array}{l}\text { Daily site temperature and relative humidity } \\
\text { readings were used to calculate VPD }(\mathrm{Pa}) \text {, } \\
\text { following Allen et al. (1998). }\end{array}$ \\
\hline Freezing da: & Freezing $_{\text {ext }}$ & Number of days with temperatures below $0^{\circ} \mathrm{C}$. \\
\hline Northwest wind shelter & Wind_Shelter $_{n \mathrm{w}}$ & $\begin{array}{l}\text { Shelter from the strong northwest }\left(310^{\circ}, \pm 80^{\circ}\right) \\
\text { wind (the inverse of exposure). The northwest wind } \\
\text { is the direction of the strongest gusts and } \\
\text { predominant wind direction on the island (Adams } \\
2009 \text { ). }\end{array}$ \\
\hline Fine gravel content & Fine_Gravel & $\begin{array}{l}\text { Proportion of fine gravel }(6-2 \mathrm{~mm}) \text {, as an } \\
\text { indication of water holding capacity. }\end{array}$ \\
\hline
\end{tabular}

Table 2. Total cover of Azorella macquariensis and the proportion (\%) of each condition class (Healthy, Wind-scour, Dieback and Recovery) and dieback progression subclasses (Active, Thinning,

660 Advanced) averaged across six plots at 62 sites across Macquarie Island.

\begin{tabular}{lcccc}
\hline Condition class & $\mathrm{N}$ & Min. & Max. & Mean $( \pm$ s.e. $)$ \\
\hline Healthy (\%) & 62 & 6.0 & 100.0 & $67.8( \pm 3.19)$ \\
Wind-scour (\%) & 62 & 0 & 13.4 & $1.5( \pm 0.30)$ \\
Dieback (\%) & 62 & 0 & 86.9 & $29.7( \pm 3.08)$ \\
Active Dieback (\%) & 62 & 0 & 26.9 & $3.0( \pm 0.77)$ \\
Thinning Dieback (\%) & 62 & 0 & 54.3 & $13.0( \pm 1.83)$ \\
Advanced Dieback (\%) & 62 & 0 & 85.6 & $13.7( \pm 2.50)$
\end{tabular}




\begin{tabular}{ccccc} 
Recovery (\%) & 62 & 0 & 15.3 & $1.1( \pm 0.38)$ \\
\hline Island-wide A. macquariensis cover (\%) & 62 & 0.5 & 88.3 & $41.7( \pm 2.73)$
\end{tabular}

661

662

663

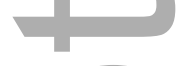

664

Fig. 1. A. Healthy Azorella macquariensis cushions with Pleurophyllum hookeri and graminoid epiphytes (central region of Macquarie Island, MI, south of Lake Prion). B. Active dieback (yellow to brown) spreading through a thin A. macquariensis mat, which is subsequently replaced with the dominant grass Agrostis magellanica (central region of MI) (see models in Hoffmann et al. 2019).

668

669

Fig. 2. Location of Macquarie Island (A) and survey sites on the island (B, black circles), with the island divided into three equal latitudinal regions. Proportion of Azorella macquariensis (\%, with standard error bars) within each Dieback progression class (Active, Thinning and Advanced) in each region is presented individually. Dieback progression classes that are significantly different across regions (i.e. north, central and south) are indicated on the figure by a different letter, the same scale is used across classes and subclasses, hill shading is included across the island. For the distribution of healthy, wind-scour and recovery classes see Fig. S1.1. Appendix S1.

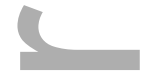

Fig. 3. Summer growing season (October - March) microclimate site values for three equal latitudinal regions across Macquarie Island, between December 2016 and February 2017 (Median with box representing upper and lower quartile, bars represent range). North $(n=15)$, central $(n=29)$, south (n =18). Significant difference between regions denoted by different shades of grey $(\mathrm{p}=0.05)$. (A.)

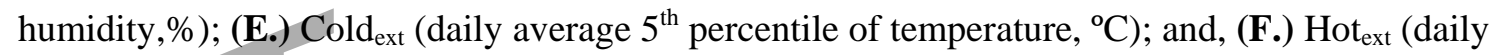
average $95^{\text {th }}$ percentile of temperature, ${ }^{\circ} \mathrm{C}$ ).

Fig. 4. (A.) Relative effect size of correlates of Azorella macquariensis dieback, positive (to the right of zero) and negative (to the left). Standardised regression coefficients ( $\pm 95 \mathrm{CI})$ from beta regression 
689 models, using growing season (Oct - Mar) microclimate and terrain variables. Significant variables 690 indicated in bold $(*, p<0.05)$. Freezing ${ }_{\text {ext }}$ (number of days with temperatures $<0^{\circ} \mathrm{C}$ ), Humidity ${ }_{\text {ext }}$ 691 (average daily $95^{\text {th }}$ percentile of relative humidity, \%), VPD (average daily vapour pressure deficit, $692 \mathrm{kPa}$ ), NW Windshelter (no unit, inverse of wind exposure), Fine Gravel (\%) and covariate, mean A. 693 macquariensis Cover (\%) at site. (B.) Relationship between significant variables Humidity ext and

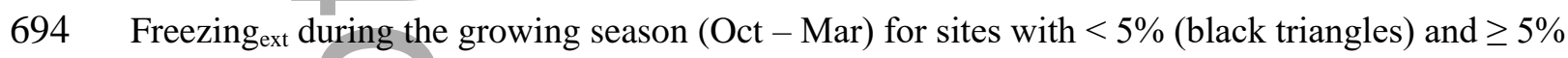
695 (grey circles) A. macquariensis dieback. Generalised linear regression lines showing a significant

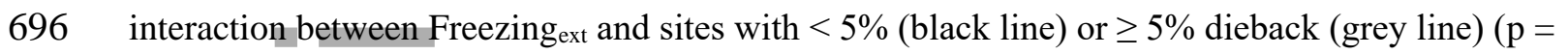
697 0.002).

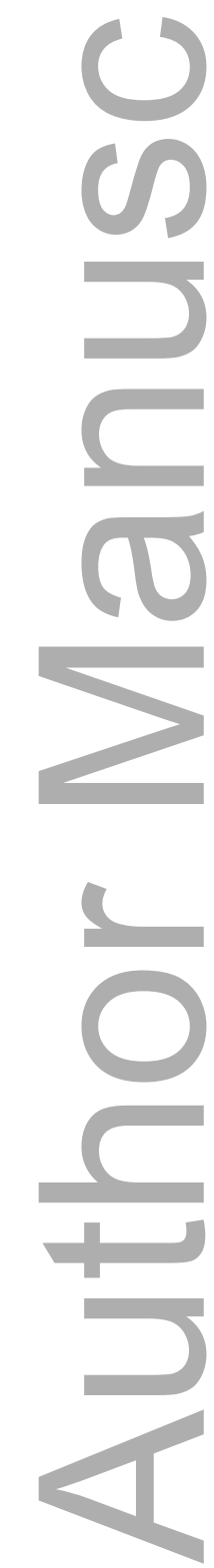




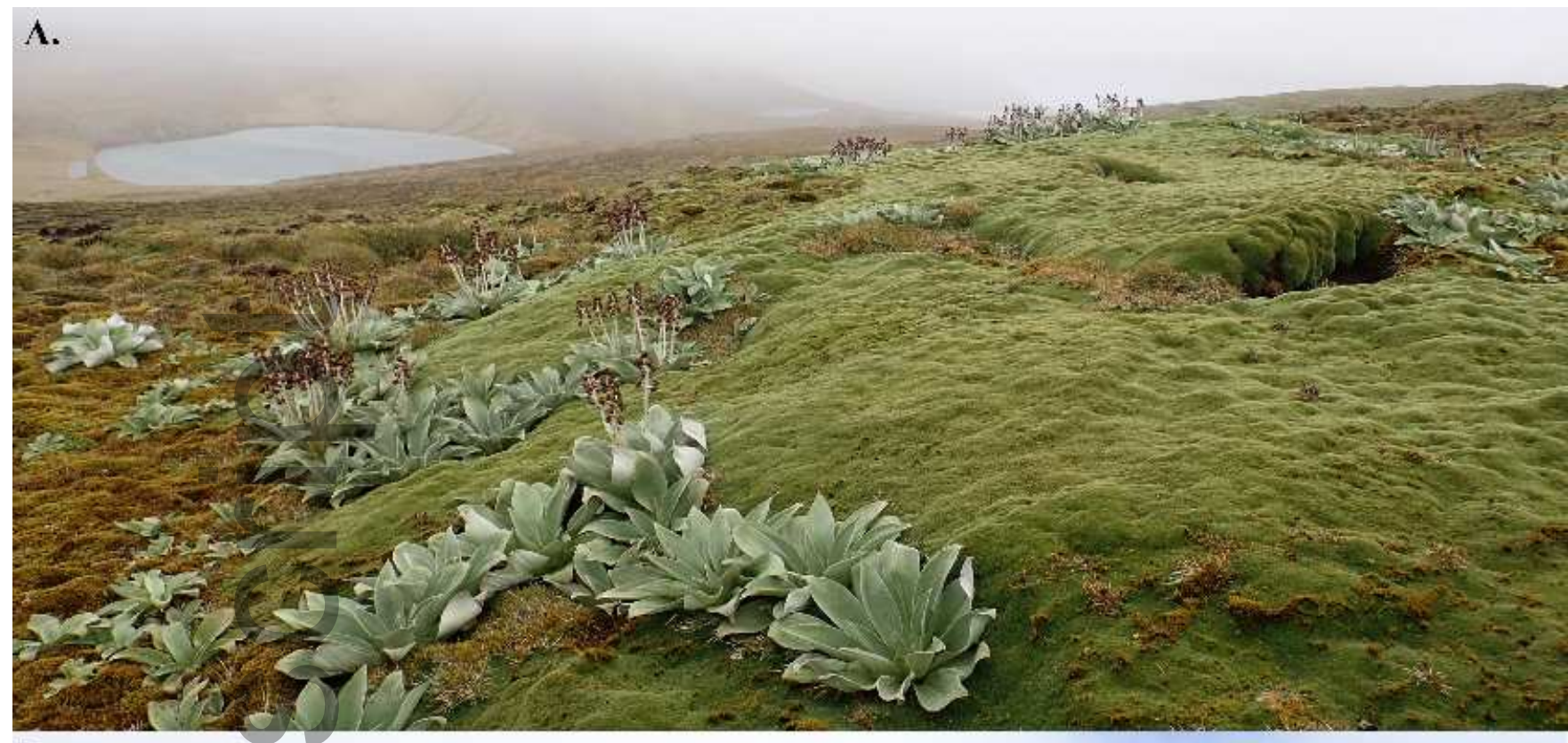

B.
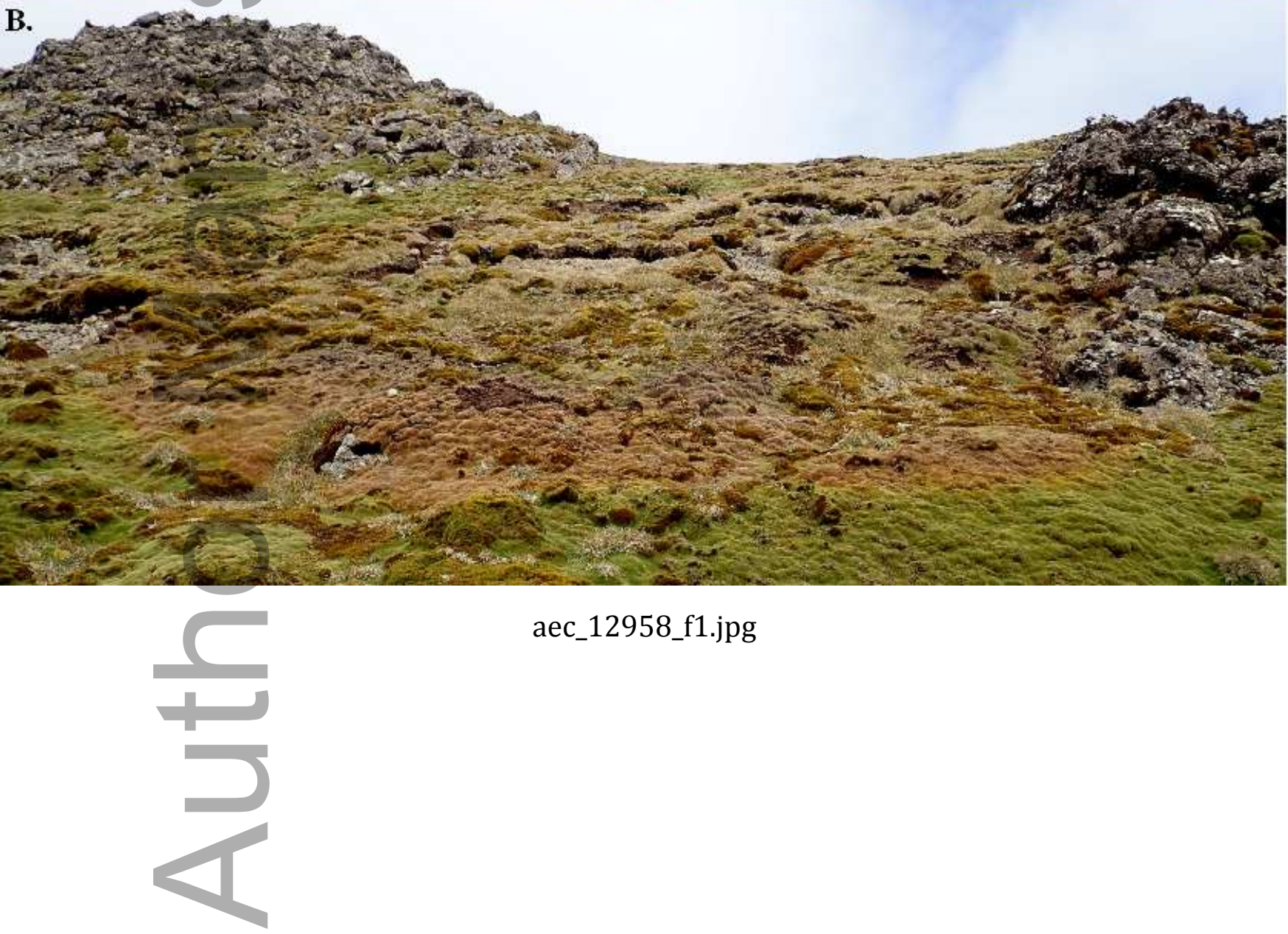

aec_12958_f1.jpg

This article is protected by copyright. All rights reserved 


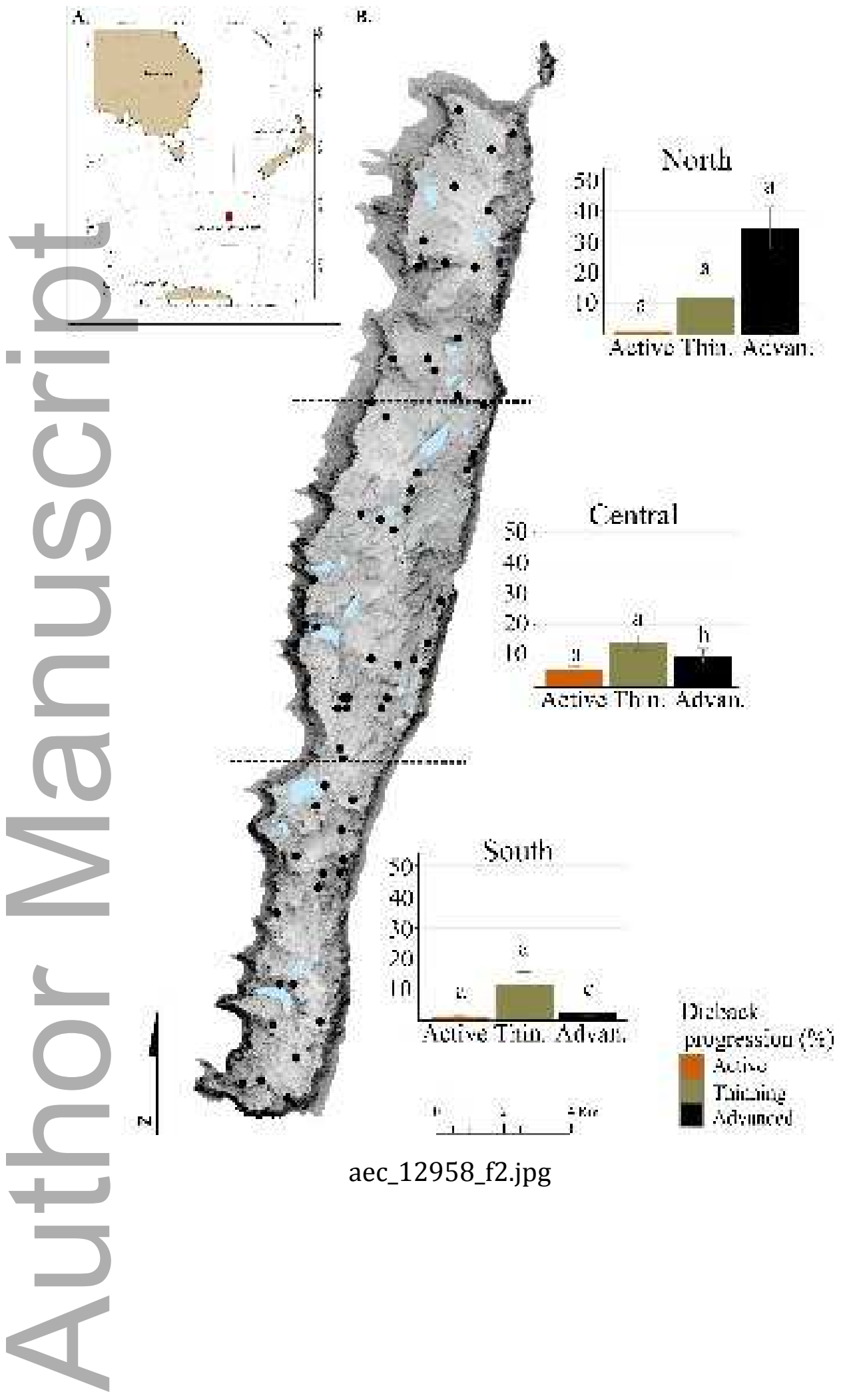

This article is protected by copyright. All rights reserved 
A.

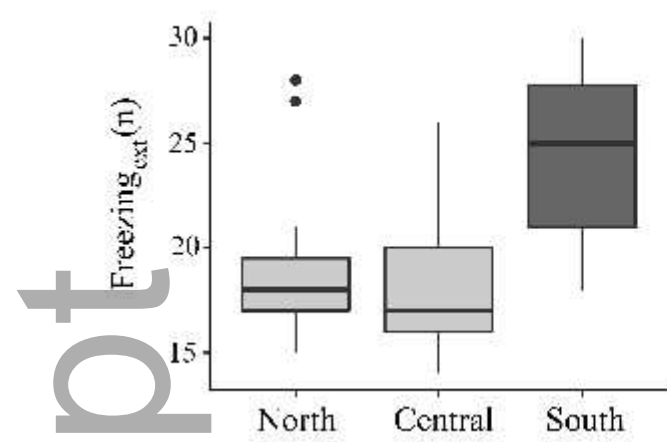

C.

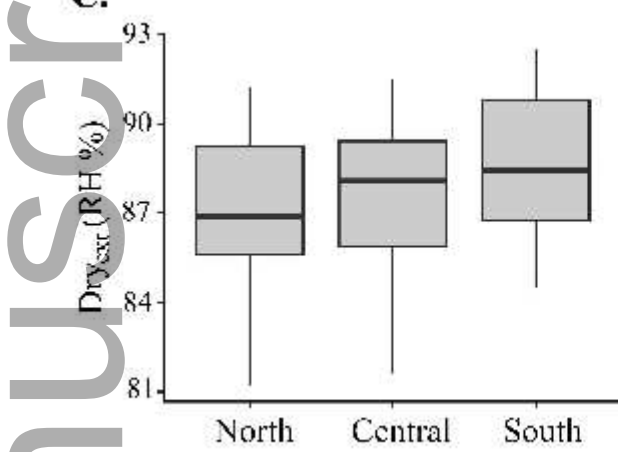

E.

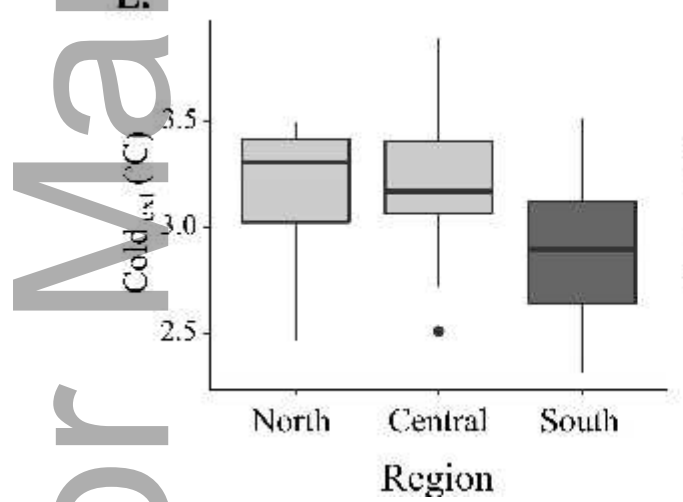

$\square$

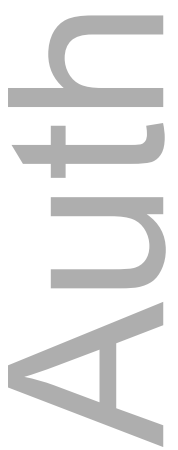

B.

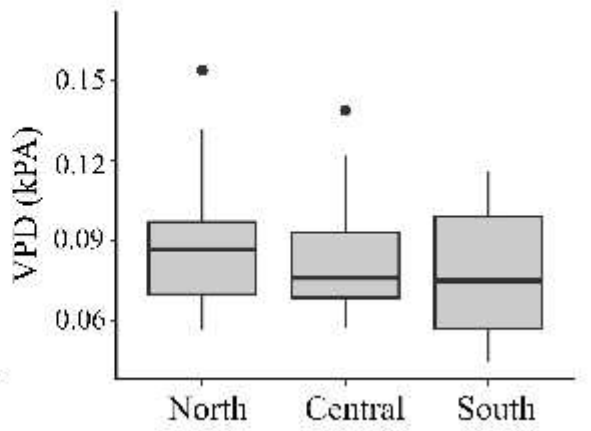

D.

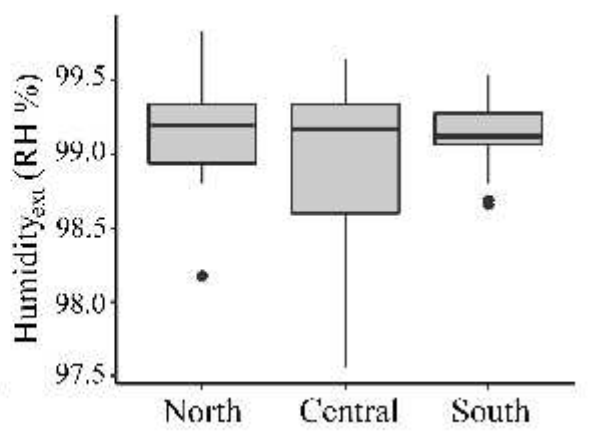

F.

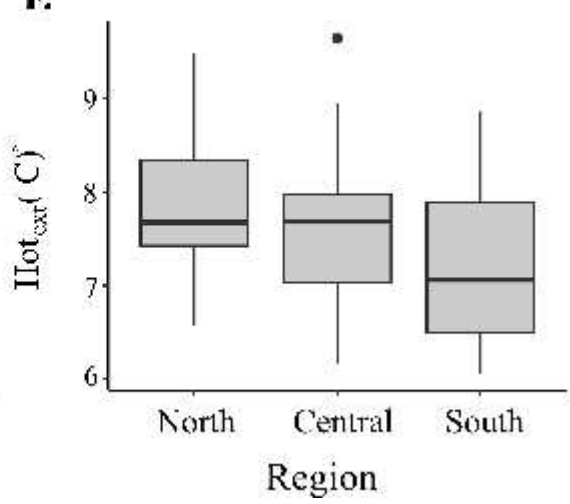

aec_12958_f3.jpg 


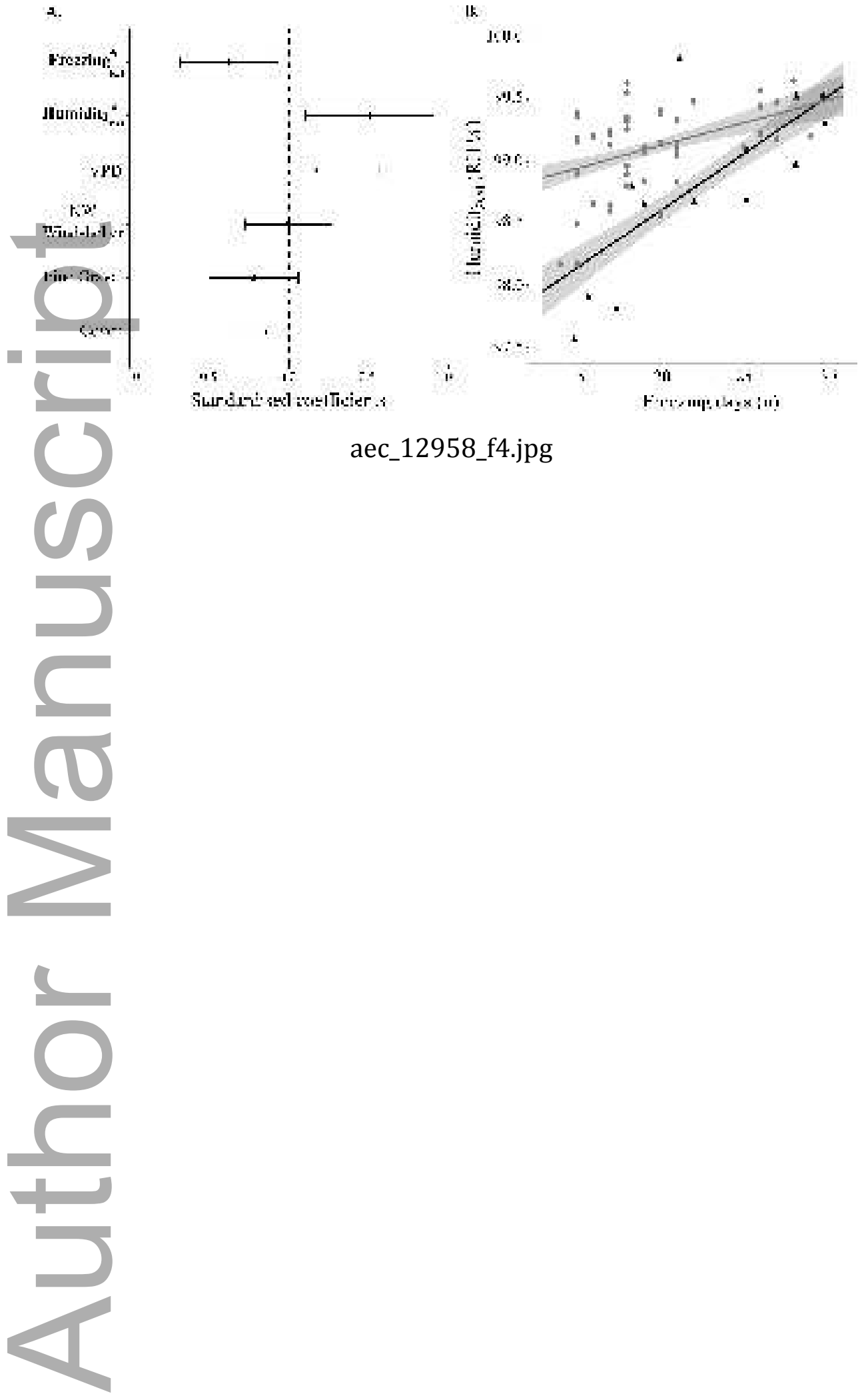




\section{University Library}

\section{- M M I E E R VA A gateway to Melbourne's research publications}

Minerva Access is the Institutional Repository of The University of Melbourne

\section{Author/s:}

Dickson, CR;Baker, DJ;Bergstrom, DM;Brookes, RH;Whinam, J;McGeoch, MA

Title:

Widespread dieback in a foundation species on a sub-Antarctic World Heritage Island: Finescale patterns and likely drivers

\section{Date:}

2021-02-01

\section{Citation:}

Dickson, C. R., Baker, D. J., Bergstrom, D. M., Brookes, R. H., Whinam, J. \& McGeoch, M. A. (2021). Widespread dieback in a foundation species on a sub-Antarctic World Heritage Island: Fine-scale patterns and likely drivers. Austral Ecology: a journal of ecology in the Southern Hemisphere, 46 (1), pp.52-64. https://doi.org/10.1111/aec.12958.

Persistent Link:

http://hdl.handle.net/11343/276439 